\title{
Strangulated urethral prolapse in a postmenopausal woman presenting as acute urinary retention
}

\author{
Ashish Sharma, Gaurav Garg, Bhupendra Pal Singh, Siddharth Pandey
}

Urology, King George's Medical University, Lucknow, Uttar Pradesh, India

Correspondence to Dr Gaurav Garg, gougarg@gmail.com

Accepted 24 September 2018

\section{DESCRIPTION}

A 48-year-old woman presented with acute urinary retention for 1 day and severe periurethral pain for last 3 days. She also revealed a history of occasional blood spotting of undergarments, dysuria and a protruding mass from the urethra for the last 3 months. Her medical/surgical and personal histories were unremarkable. Her obstetric history revealed presence of three normal vaginal deliveries and menopause at the age of 45 years. Local examination revealed presence of irreducible dusky red oedematous tender donut-shaped swelling measuring $2 \times 2 \mathrm{~cm}$ around the urethral orifice suggestive of strangulated urethral prolapse (figure 1). A gentle attempt at reduction of the prolapsed mass was done under sedation which was successful following which a Foley catheter was placed. Cystourethroscopy revealed excess urethral mucosa with normal bladder mucosa. Ultrasonography of the abdomen was suggestive of normal bladder parameters with bilateral normal upper tracts. After proper counselling and consent, the patient was taken for surgery under general anaesthesia. The prolapsed urethral mucosa was circumferentially excised around the Foley catheter, and the healthy urethral mucosal

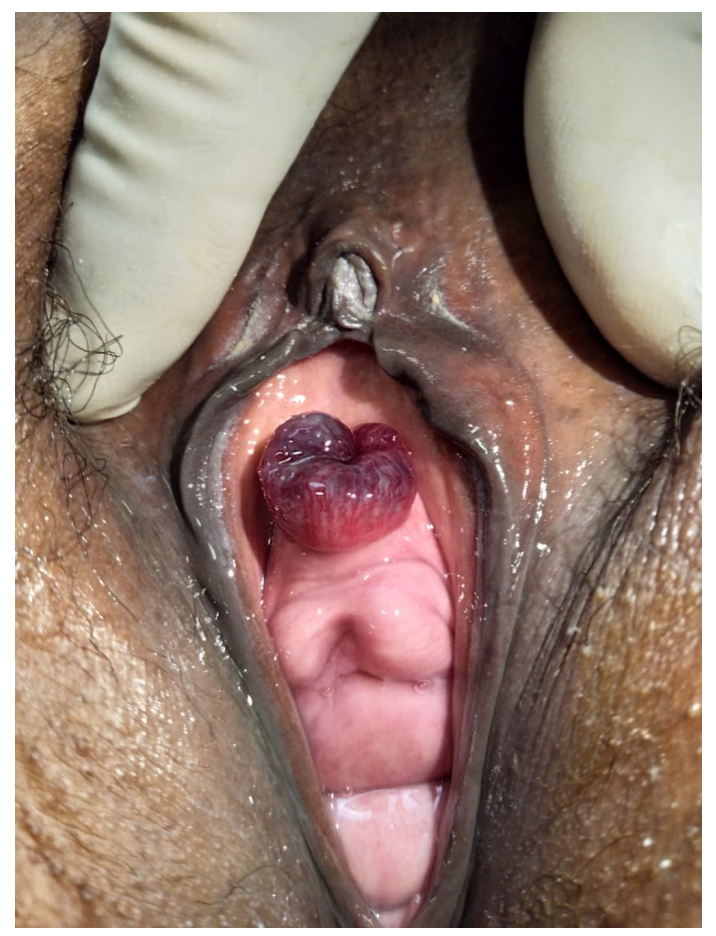

Figure 1 Clinical image showing strangulated dusky red oedematous donut-shaped urethral prolapse around urethral orifice.

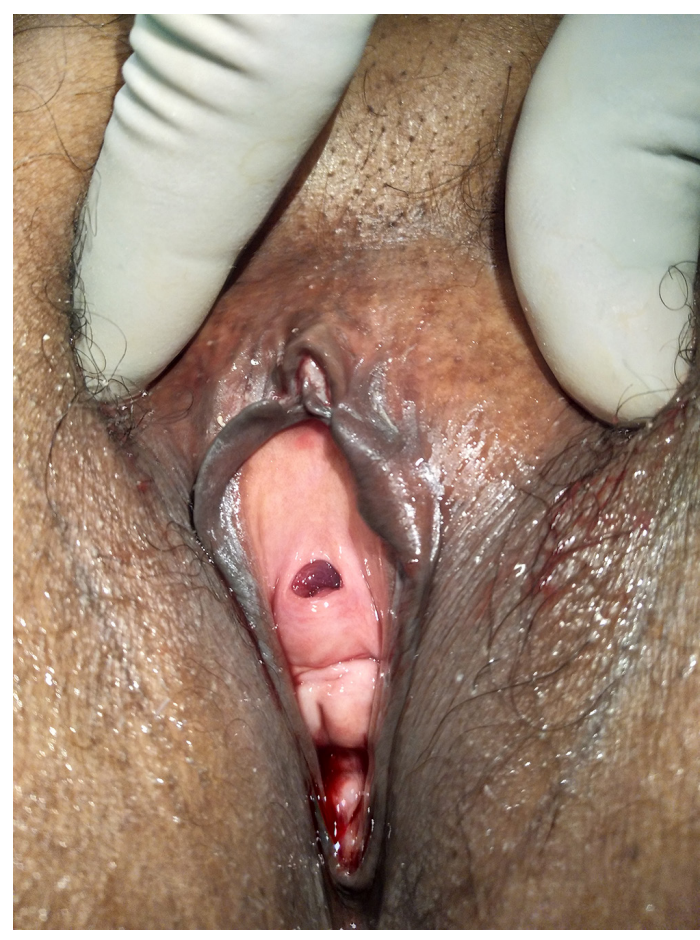

Figure 2 Postoperative clinical image showing resolution of the urethral prolapse.

margin was sutured to the vestibule using absorbable suture. The histopathological examination (HPE) revealed ulcerated oedematous urethral tissue lined with transitional cells with lymphocytic infiltration and congested vessels. She was advised for local application of oestrogen cream. The patient is voiding well at the 3-month follow-up, and local examination revealed no prolapse (figure 2).

Urethral prolapse is a rare clinical entity, and strangulated urethral prolapse is an even rarer urological emergency. It occurs due to circular protrusion of urethral mucosa through the urethral meatus with bimodal age distribution, mostly seen in either prepubertal girls or postmenopausal women. ${ }^{1}$ The exact aetiology is still unknown; however, lack of oestrogen and poor pelvic support have been implicated as major predisposing factors, especially in postmenopausal women. As the size of the protruding mass increases, the vascularity is compromised due to extrinsic compression at urethral meatus leading to strangulation which results in venous congestion, thrombosis and necrosis of the prolapsed urethral tissue. Patients with strangulated urethral prolapse mostly present with vaginal bleeding with periurethral mass and/ or voiding symptoms like dysuria, frequency and so 
on. ${ }^{12}$ In extreme cases, it may present with acute urinary retention. The circumferential excision of prolapsed urethral mucosa and buttressing of remaining urethral wall to vestibule margin followed by long-term oestrogen cream application are considered as a standard treatment. ${ }^{3}$

\section{Learning points}

Strangulated urethral prolapse is an extremely rare urological emergency.

- Rarely urethral mucosal prolapse may strangulate at meatus opening and may present with acute urinary retention.

- Surgical excision and long-term oestrogen cream application are considered as a standard treatment.
Contributors GG: concept, design, supervision, processing, writing manuscript and critical analysis. AS: concept, design, supervision, processing, writing manuscript and critical analysis. BPS: supervision, processing, writing manuscript and critical analysis. SP: concept, supervision, writing manuscript and critical analysis.

Funding The authors have not declared a specific grant for this research from any funding agency in the public, commercial or not-for-profit sectors.

Competing interests None declared.

Patient consent Obtained.

Provenance and peer review Not commissioned; externally peer reviewed.

\section{REFERENCES}

1 Abouzeid H, Shergill IS, Al-Samarrai M. Successful medical treatment of advanced urethral prolapse. J Obstet Gynaecol 2007:27:634-5.

2 Jiménez Parra JD, Cebrián Lostal JL, Lozano Uruñuela F, et al. [Urethral prolapse in postmenopausical women]. Actas Urol Esp 2010;34:565-7.

3 Green J, Brodie A, Tassadaq T. A rare case of urethral prolapse in a postmenopausal woman. BMJ Case Rep 2017;2017:bcr-2017-222182.

Copyright 2018 BMJ Publishing Group. All rights reserved. For permission to reuse any of this content visit http://group.bmj.com/group/rights-licensing/permissions.

BMJ Case Report Fellows may re-use this article for personal use and teaching without any further permission.

Become a Fellow of BMJ Case Reports today and you can:

- Submit as many cases as you like

- Enjoy fast sympathetic peer review and rapid publication of accepted articles

- Access all the published articles

- Re-use any of the published material for personal use and teaching without further permission

For information on Institutional Fellowships contact consortiasales@bmjgroup.com

Visit casereports.bmj.com for more articles like this and to become a Fellow 